\title{
Effect of dilution of broiler chicken diet with cracked maize on performance and intestinal morphology
}

\author{
K. Jelveh 1 , B. Rasouli 1 , A. Seidavi ${ }^{1,5}$, P. Makovicky'2, E. Hatzigiannakis ${ }^{3}$ and Ch. Milis ${ }^{4}$ \\ ${ }^{1}$ Rasht Branch, Islamic Azad University, Faculty of Agriculture, Department of Animal Science \\ Pole-Taleshan, Rasht, P.O. Box: 41335-3516, Iran \\ 2 J. Selye University, Department of Biology, Bratislava 3322, 94501 Komárno, Hradná 21, Slovakia \\ ${ }^{3}$ National Agricultural Research Foundation, Soil and Water Resources Institute, 57400, Sindos Thessaloniki, Greece \\ ${ }^{4}$ Hellenic Ministry of Rural Development and Foods, Department of Agricultural Applications of Central Macedonia \\ 57400, Sindos Thessaloniki, Greece
}

KEY WORDS: diet, particle size, protein level, broiler chickens, maize, digestive system

Received: $\quad 12$ June 2020

Revised: $\quad 30$ July 2020

Accepted: 17 September 2020

${ }^{5}$ Corresponding author:

e-mail: alirezaseidavi@iaurasht.ac.ir

\begin{abstract}
The aim of the study was to evaluate the effects of dilution of broiler diet with cracked maize on performance and intestinal morphology. In total 576 male Ross 308 broiler chickens (10 day old) were used in the study. Animals according to a completely randomized trial were assigned to four treatment groups with 8 replications each. Diets differeing in cracked maize levels were: 1) control (CON) - without cracked maize, 2) low dilution rate (LDR) - CON + 4 (day $10-20$ of age, $1^{\text {st }}$ period), 8 (days $21-30$ of age, $2^{\text {nd }}$ period) and $12 \%$ (day $31-42$ of age, $3^{\text {rd }}$ period) of cracked maize, 3 ) medium dilution rate (MDR) $-\mathrm{CON}+6$ ( $1^{\text {st }}$ period), 12 ( $2^{\text {nd }}$ period) and $20 \%$ ( $3^{\text {rd }}$ period) of cracked maize, 4 ) high dilution rate (HDR) $-\mathrm{CON}+6$ ( $1^{\text {st }}$ period $), 15$ ( $2^{\text {nd }}$ period $)$ and $25 \%$ ( $3^{\text {rd }}$ period) of cracked maize. Body weight gain and feed intake did not differ between treatments. Feed conversion ratio was positively affected in the treatments diluted with cracked maize. These effects were visible in the higher relative weight of gizzard and villi height in the duodenum and ileum $(P<0.05)$ in groups fed LDR, MDR and HDR diets in comparison to those fed CON diet.
\end{abstract}

\section{Introduction}

Beneficial effects of whole or cracked grains in isonitrogenous broiler chicken diets have been reported, especially when cracked maize substitutes, by weight, ground maize (Clark et al., 2009; Singh et al., 2014). On the other hand, cracked maize added to broiler chicken diets (by sequential dilution of a starter diet up to a level of $40 \%$ ) negatively affect feed conversion ratio (FCR), due to lower crude protein (CP) content of the diet (Sharma et al., 2012). Pacheco et al. (2013) reported that starter diets should contain a small percentage of coarse maize particles, which should then gradually increase with body weight and age of animal since the gradual dilution of complete diets with whole grains may assure more accurate meeting of nutrient requirements for broiler chickens (Sharma et al., 2012). According to Plavnik et al. (2002), when lower dilution percentages are applied, specifically when commercial starter and grower diets are diluted with 50 and $150 \mathrm{~g}$ of whole wheat per $\mathrm{kg}$ of diet, respectively, there are no significant changes in carcass and breast yield in broiler chickens. The main benefits of feeding whole wheat grain are improved gut health and digestion, mainly FCR increased up to $8 \%$ and reduced mortality (Svihus, 2010). In opposite, Amerah et al. (2008) found lower carcass yield, but similar breast yield by replacing ground wheat with whole wheat. Additionally, the results of studies examining the effects of feed particle size on the upper gastrointestinal tract development have been inconclusive (Naderinejad 
et al., 2016), because of the confounding effects of feed form (mash vs pellets) that is replaced by whole or cracked grains. Cracked maize fed to broilers increased weight gain and gizzard size, and had a positive effect on gut microflora. According to Singh et al. (2014) coarse maize could totally replace, by weight, ground maize in mash diets fed to broilers. More specifically, in this study broilers were fed either $600 \mathrm{~g} / \mathrm{kg}$ of finely ground maize or the ground maize was replaced with $150,300,450$ or $600 \mathrm{~g} / \mathrm{kg}$ of coarse maize. Each diet was fed in mash form and offered free-choice from 11 to 35 days after hatch. The more coarse maize was added to the bird diets, the more body and gizzard weight increased, with no effect on carcass yield. Beneficial bacteria counts (Lactobacillus, Bifidobacteria) were increased, whilst undesirable bacteria counts (Clostridium, Campylobacterium, Acteroides) were decreased as levels of coarse maize increased.

It seems that the level of dilution, during productive cycle, set to meet the changing $\mathrm{CP}$ needs, as well as the level of cracked grain inclusion within each stage of production, are both critical and have not been determined yet. Moreover, the possible effects on the anatomy of the small intestine are not well documented, because the positive effects of feeding chickens whole grains have been solely associated with an improvement in gut development and health due to the stimulation of the gizzard $(\mathrm{Xu}$ et al., 2015), and changes in the intestinal morphology and the microbiota profile (Shabani et al., 2015; Zaefarian et al., 2016). Since, the substitution, by weight, of ground maize with cracked maize without negative effect is well documented, the aim of the present study was to evaluate whether cracked maize, and to which extent, is able to replace (dilution) the whole diet not only ground maize, within each production cycle and apart from production cycle, and thus diminishing protein content of broiler chicken diets. Even though maize is considered to be the reference energy source in animal nutrition, there are very few reports regarding its particle size effect on the performance of broiler chicken in comparison to other grains (Singh et al., 2014). Therefore, four treatments with different cracked maize dilutions were used to assess the effects on performance, as though as to examine the anatomical effects on the digestive system, within 42-day broiler chicken production cycle. The aim of the study was to evaluate the live performance of broilers in response to coarse maize and determine the threshold of coarse maize inclusion into broiler diets that would elicit a live performance response, either positive or negative.

\section{Material and methods}

\section{Treatments and experimental design}

A completely randomized design with 4 treatments differing in cracked maize levels was used. In each treatment group were 8 replicate pens of 18 broiler chickens each, giving a total of 32 experimental units. The study was approved by the Ethic Committee of the Islamic Azad University, Rasht Branch, and adhered to the International Guidelines for research involving animals (Directive 2010/63/ EU). Care was taken to minimize the number of animals used.

Commencing from day one, treatments were as follows:

- treatment I = control diet without cracked maize $(\mathrm{CON})$, calculated to meet energy and protein requirements according to Aviagen (2009);

- treatment II = low dilution rate (LDR) diet: $\mathrm{CON}+4$ (days 10 to 20 of age, $1^{\text {st }}$ period), 8 (days 21 to 30 of age, $2^{\text {nd }}$ period) and $12 \%$ (days 31 to 42 of age, $3^{\text {rd }}$ period) of cracked maize (mean 2.5\%, relative, lower CP content than in CON diet);

- treatment III = medium dilution rate (MDR) diet: CON $+6\left(1^{\text {st }}\right.$ period $), 12\left(2^{\text {nd }}\right.$ period $)$ and $20 \%$ ( $3^{\text {rd }}$ period) of cracked maize (mean $4 \%$, relative, lower $\mathrm{CP}$ content than in $\mathrm{CON}$ diet);

- treatment IV = high dilution rate (HDR) diet: $\mathrm{CON}+6\left(1^{\text {st }}\right.$ period $), 15\left(2^{\text {nd }}\right.$ period $)$ and $25 \%$ $\left(3^{\text {rd }}\right.$ period) of cracked maize (mean $6 \%$, relative, lower $\mathrm{CP}$ content than in $\mathrm{CON}$ diet).

\section{Physical form of diets}

Diets were fed as crumble from days 1 to 30 of age and then fed as pellet from days 31 to 42 of age. Crumble was produced using a Roller Crumbler (Crumbler 10 to $20 \mathrm{t} / \mathrm{h}, 560 \mathrm{rpm}$, type sslg20*170) (Zhengchang Co, Shanghai, China) device. Pellets were produced using a Pellet Mill (Model SZLH420D, $110 \mathrm{~kW}, 3$ to $15 \mathrm{t} / \mathrm{h}$ ) (Zhengchang Co, Shanghai, China) device. Cracked maize for treatments LDR, MDR and HDR was added to CON crumble/pellet diet. Maize was cracked as coarse particle size using the Roller Crumbler (Crumbler 10 to $20 \mathrm{t} / \mathrm{h}, 560$ rpm, type sslg20*170) (Zhengchang Co, Shanghai, China) device. Cracked maize had particle size as much as $\leq 1$ (1\%), 1-2 (22.8\%), 2-3 (26.7\%) and $\geq 3 \mathrm{~mm}(49.5 \%)$. Maize in CON treatment was milled using Hammer Mill (160 kw, Model SFSP, 1400 rpm) device with a 3-mm mesh (Zhengchang Co, Shanghai, China). Milled maize had particle size as much as $\leq 1(73.2 \%), 1-2(23.8 \%), 2-3(2.6 \%)$ and $\geq 3 \mathrm{~mm}(0.4 \%)$. 
-

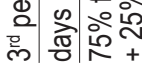

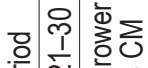

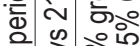

సे 잉

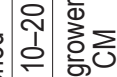

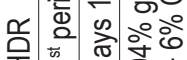

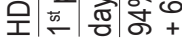

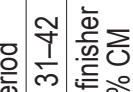

ळ

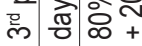

은

ฮั่

సे

일일

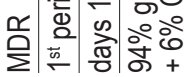

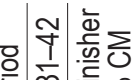

๗

항 坖

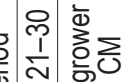

ํํㅊ

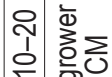

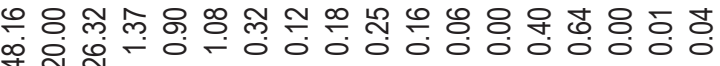

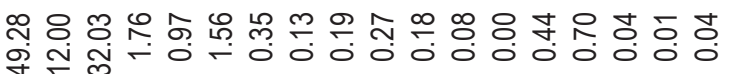

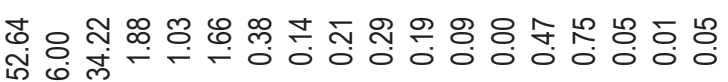

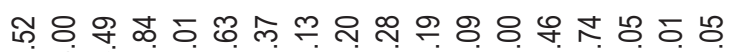
in m

\section{ษ $\frac{\grave{\Phi}}{\text { क }}$}

$\frac{Y}{m} \stackrel{\frac{D}{E}}{=}$

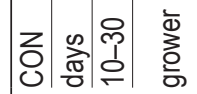

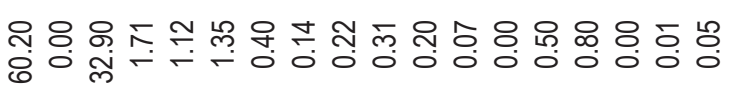

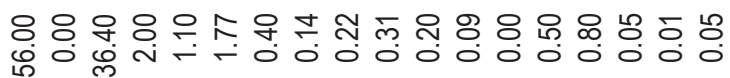

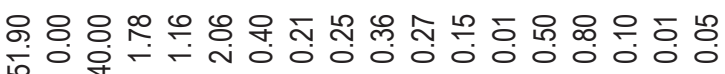

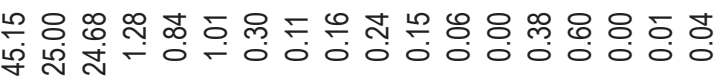

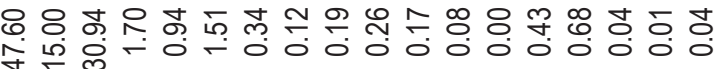

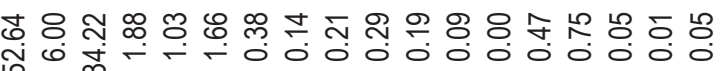

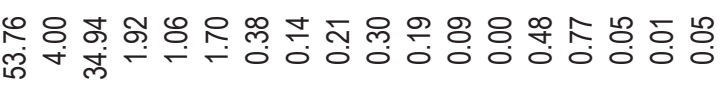

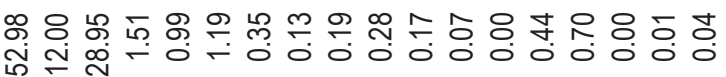

$\infty$

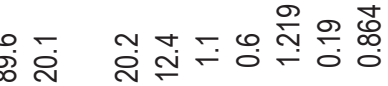

ก

ஓं

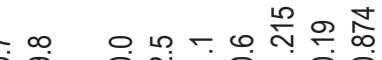

வ

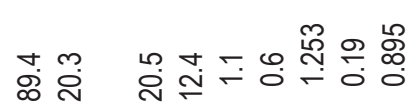

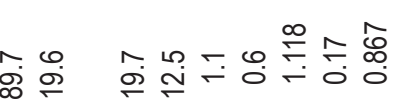

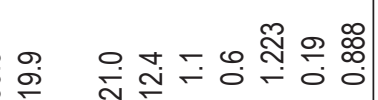

ळ

ง

ஓं

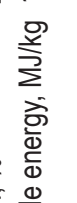

윤

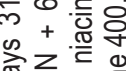

웡워

ิㅡㄴ 1 용

त

은 등융

든 긓

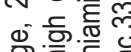

要丰至

이ㅇㅜㅗ옹ㅇㅇㅇ

으 요음으

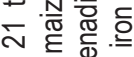

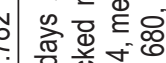

केष

응 은 은 뜽

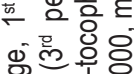

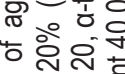

오은 흔 줒

으은 언

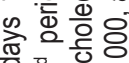

氙

$+\div-$

응 흐음응

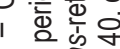

类

$+E 6$

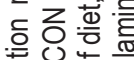

름 1 융

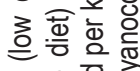

또웧ㅇ

드응응

출 응

얼 톨 는

는 웡

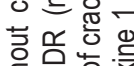
$\sum$ 응

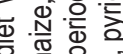
1 는 응흥

Nㅗㅇ 음

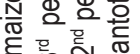
व 뉸 ฯ ₹ 


\section{Chemical analysis}

Chemical composition of the diets is shown in Table 1. Feed samples were ground to pass through a 1-mm screen (AOAC International, 2006, official method 950.02B). Dry matter (DM) was determined by drying in an oven (AOAC International, 2006, official method 934.01). The CP was measured as Kjeldahl $\mathrm{N} \times 6.25$ (AOAC International, 2006, official method 984.13). For all methods, measurements were made in triplicate and standards were included in each run of each method.

\section{Measurements of broiler performance, and carcass and intestinal morphology traits}

Feed intake (FI), body weight gain (BWG) and feed conversion ratio (FCR) were recorded weekly and at the beginning of each period. Carcass measurements and intestinal morphology traits were measured at the end of the experiment. Carcass measurements were performed as described by Ebrahimi et al. (2013). Briefly, at day 42 of age after $4 \mathrm{~h}$ of fasting two broiler chickens from each two replicates were euthanized ( 8 per treatment). Selected birds were euthanized by cervical dislocation, and gizzard, proventriculus and small intestine were then excised, separated, opened, rinsed free of digesta, dried and weighed individually. Each bird was considered a repetition.

Chickens with the body weight the best corresponding with group mean body weight were choosen. These animals were used for measuring carcass yield, distribution of meat and for estimating gastrointestinal tract characteristics. Broiler chickens were fully pecked by the dry pecking method. Feet were separated from the carcass in the tibio-tarsal joint. Neck, wing tips, gut and liver were removed and the empty or edible carcass was weighed and intestinal segment dimensions were recorded. Various parts of the carcasses were dissected and separately weighed. First, breast muscles including skin and sternum were dissected free from the carcass. Legs (thighs and drumsticks) were dissected by ex-articulation in the hip joint and then tissue was separated from the iliac bone. All abdominal fat, including that around the rectum, gizzard and proventriculus was collected. Villi height, crypt depth, villi height:crypt depth ratio, villi width, thickness of epithelium and number of Goblet cells were estimated based on Hosseini et al. (2017). In more detail, the gizzard was opened and weighed after its content was removed. After removal, the small and large intestines were cut in segments, weighed and measured. The small intestine was measured between from the site where the duodenum emerges from the gizzard and the beginning of the caeca, and the large intestine length included the length of the colon and the rectum, adding the length of the caeca. Four semi-serial sections with $7-\mu \mathrm{m}$ thickness were placed in each slide. Slides were died using the method of the periodic acid of Schiff (PAS). Two segments measuring approximately $3 \mathrm{~cm}$ of the duodenum, jejunum and ileum were cross-sectioned and longitudinally opened by the mesenteric edge. Samples were washed in phosphate buffer solution at $0.1 \mathrm{M}(\mathrm{pH}$ 7.4) and fixed in Bouin solution for 3 days. Samples were then trimmed to eliminate the torn edges, and remained for further $24 \mathrm{~h}$ in the fixing solution. Samples were then washed in ethanol at $70 \%$ to remove the fixing solutions, dehydrated in graded series of alcohol, cleared in xylol and embedded in 'paraplast'. Using an image capture and analysis system (Image-Pro Plus version 4.5, 0.27), villi height and perimeter and crypt depth were measured and goblet cells were counted in duodenum, jejunum and ileum sections. Villus height was measured from the basal region, which starts at the higher portion of the crypts, until villus tip, whereas crypt depth was measured from the base up to the crypt-villi transition region. Perimeter was measured around the border where microvilli were located. Goblet cell number and Goblet cell:epithelial cell ratio were determined by counting 500 epithelial cells and all Goblet cells per slide.

The total weight of all dissected parts and the weights of various segments of the digestive tract were related to the totally eviscerated carcass. The ratios were calculated according to the following formula:

[(weight of component (s) / eviscerated carcass weight) $\times 100$ ].

\section{Statistical analysis}

Shapiro-Wilk's test confirmed the normal distribution of data, which were analyzed by the use of least square analyses of variance and covariance (univariate analysis of variance, ANOVA), with dependent variables being levels of cracked maize inclusion and CP content of the diet as a covariance (GLM SAS procedure; SAS Institute, 2003). Except $\mathrm{CP}$, nutrient densities of diets were not significant and were excluded from the model. Means were obtained by using the least square (LS) means option of SAS, and differences among treatments were explored by using the Tukey test for multiplecomparison analysis. Differences were declared significant when $P<0.05$. 
Table 2. Performance of Ross 308 male broiler chickens fed different levels of cracked maize

\begin{tabular}{|c|c|c|c|c|c|c|}
\hline Indices & $\mathrm{CON}$ & LDR & MDR & HDR & SEM & $P$-value \\
\hline Live body weight at day 1 & 45 & 44 & 45 & 44 & 3.1 & 0.954 \\
\hline Live body weight at day 10 & 314 & 315 & 313 & 312 & 9.2 & 0.918 \\
\hline Mortality rate, $\%$ & 0.6 & 0.6 & 0.6 & 0.6 & 0.02 & 0.985 \\
\hline \multicolumn{7}{|l|}{ Days 10 to 20 of age } \\
\hline feed intake, $g$ & 747 & 718 & 695 & 723 & 8.3 & 0.202 \\
\hline weight gain, $g$ & 537 & 520 & 503 & 513 & 7.2 & 0.405 \\
\hline feed conversion ratio, $\%$ & 1.39 & 1.38 & 1.38 & 1.40 & 0.01 & 0.384 \\
\hline \multicolumn{7}{|l|}{ Days 21 to 30 of age } \\
\hline feed intake, g & 1176 & 1167 & 1149 & 1155 & 18.2 & 0.734 \\
\hline weight gain, $g$ & $699^{a}$ & $782^{b}$ & $757^{b}$ & $766^{b}$ & 9.4 & 0.026 \\
\hline feed conversion ratio, $\%$ & $1.68^{\mathrm{a}}$ & $1.49^{b}$ & $1.52^{\mathrm{b}}$ & $1.51^{\mathrm{b}}$ & 0.02 & 0.027 \\
\hline \multicolumn{7}{|l|}{ Days 31 to 42 of age } \\
\hline feed intake, $g$ & 1763 & 1750 & 1722 & 1733 & 30.3 & 0.875 \\
\hline weight gain, $g$ & $1015^{\mathrm{a}}$ & $1069^{b}$ & $1046^{b}$ & $1047^{b}$ & 13.2 & 0.018 \\
\hline feed conversion ratio, \% & $1.74^{\mathrm{a}}$ & $1.63^{b}$ & $1.65^{b}$ & $1.66^{b}$ & 0.02 & 0.013 \\
\hline \multicolumn{7}{|c|}{ Total period (days 10 to 42 of age) } \\
\hline feed intake, $g$ & 3686 & 3635 & 3566 & 3611 & 35.1 & 0.263 \\
\hline weight gain, $g$ & 2251 & 2371 & 2306 & 2326 & 24.2 & 0.061 \\
\hline feed conversion ratio, $\%$ & $1.64^{a}$ & $1.53^{b}$ & $1.54^{\mathrm{bc}}$ & $1.55^{\mathrm{c}}$ & 0.01 & 0.001 \\
\hline
\end{tabular}

CON - control diet without cracked maize; LDR (low dilution rate diet) - CON + 4 (days 10 to 20 of age, 1st period), 8 (days 21 to 30 of age, $2^{\text {nd }}$ period) and $12 \%$ (days 31 to 42 of age, $3^{\text {rd }}$ period) of cracked maize; MDR (medium dilution rate diet) - CON +6 ( $\left(1^{\text {st }}\right.$ period), 12 ( $2^{\text {nd }}$ period) and $20 \%$ ( $3^{\text {rd }}$ period) of cracked maize; HDR (high dilution rate diet) $-C O N+6$ ( $1^{\text {st }}$ period), 15 ( $2^{\text {nd }}$ period) and $25 \%$ ( $3^{\text {rd }}$ period) of cracked maize. Data presented as least square means; abc - means with different superscripts within the row are significantly different at $P<0.05$; SEM - pooled standard error

\section{Results}

Between days 1-10, BW of broiler chickens did not differ between treatments, neither mortality rate (Table 2). There were also no differences in FI in all groups between days 10-20, 21-30, 31-42 and the total period. Weight gain in all groups was similar between days 10-20, however it was the lowest in animals from CON group between days 21-30 and $31-42(P<0.05)$ as compared with another groups; the effect was not present in other periods (Table 2). It was found the negative correlation between the CP content of the diet and FCR. Nevertheless, FCR in animals from CON group was higher between days $21-30,31-42$ and the total period (Table 2,
$P<0.05)$, regardless higher protein content of $\mathrm{CON}$ diets (Table 1). Additionally, FCR in animals from LDR group was lower than in those from HDR group.

In animals fed LDR, MDR and HDR diets higher relative weight of the gizzard (Table 3 ) in comparison to those fed CON diet $(P<0.05)$ was observed. Eviscerated carcass, relative weight of viscera, relative weight of proventriculus and relative weight of abdominal fat were not statistically significant between animals from all treatment groups. Additionally, relative weight of filled proventriculus + gizzard was significantly lower in CON group in comparison to MDR. Lower villi height at the duodenum and ileum (Table 4) was found in animals

Table 3. Carcass characteristics of Ross 308 male broiler chickens fed different levels of cracked maize

\begin{tabular}{lcccccc}
\hline Indices & CON & LDR & MDR & HDR & SEM & $P$-value \\
\hline Eviscerated carcass, \% & 70.0 & 66.8 & 64.9 & 65.0 & 0.95 & 0.254 \\
Relative weight of viscera, \% & 13.0 & 11.7 & 12.1 & 13.1 & 0.53 & 0.228 \\
Relative weight of gizzard, \% & $0.85^{\mathrm{a}}$ & $1.19^{\mathrm{b}}$ & $1.25^{\mathrm{b}}$ & $1.37^{\mathrm{b}}$ & 0.08 & 0.029 \\
Relative weight of proventriculus, \% & 0.348 & 0.365 & 0.313 & 0.303 & 0.035 & 0.588 \\
Relative weight of filled proventriculus + gizzard, \% & $1.85^{\mathrm{a}}$ & $2.21^{\mathrm{ab}}$ & $2.79^{\mathrm{b}}$ & $2.39^{\mathrm{ab}}$ & 0.19 & 0.038 \\
Relative weight of abdominal fat, \% & 1.75 & 1.89 & 1.96 & 1.86 & 0.20 & 0.908 \\
\hline
\end{tabular}

CON - control diet without cracked maize; LDR (low dilution rate diet) - CON + 4 (days 10 to 20 of age, $1^{\text {st }}$ period), 8 (days 21 to 30 of age, $2^{\text {nd }}$ period) and $12 \%$ (days 31 to 42 of age, $3^{\text {rd }}$ period) of cracked corn; MDR (medium dilution rate diet) $-\operatorname{CON}+6\left(1^{\text {st }}\right.$ period), $12\left(2^{\text {nd }}\right.$ period) and $20 \%$ ( $3^{\text {rd }}$ period) of cracked maize; HDR (high dilution rate diet) $-\mathrm{CON}+6\left(1^{\text {st }}\right.$ period), 15 ( $2^{\text {nd }}$ period) and $25 \%$ ( $3^{\text {rd }}$ period) of cracked maize. Data presented as least square means; ${ }^{\text {abc }}$ - means with different superscripts within the row are significantly different at $P<0.05$; SEM - pooled standard error 
Table 4. Effect of different treatments on the lower tract, digestive system morphology at day 42 of age in Ross 308 male broilers chickens fed graded levels of cracked corn

\begin{tabular}{|c|c|c|c|c|c|c|}
\hline Indices & CON & LDR & MDR & HDR & SEM & $P$-value \\
\hline \multicolumn{7}{|l|}{ Duodenum } \\
\hline villi height, $\mu \mathrm{m}$ & $1387^{a}$ & $1980^{b}$ & $1923^{b c}$ & $1847^{\circ}$ & 15.2 & 0.001 \\
\hline crypt depth, $\mu \mathrm{m}$ & 329 & 247 & 252 & 293 & 15.1 & 0.144 \\
\hline villi height:crypt depth ratio & $4.24^{\mathrm{a}}$ & $8.14^{b}$ & $7.75^{\mathrm{bc}}$ & $6.31^{\mathrm{c}}$ & 0.47 & 0.001 \\
\hline villi width, $\mu \mathrm{m}$ & $152^{\mathrm{a}}$ & $202^{b}$ & $199^{b}$ & $177^{\mathrm{ab}}$ & 8.5 & 0.047 \\
\hline thickness of epithelium, $\mu \mathrm{m}$ & $49.6^{\mathrm{a}}$ & $37.8^{b}$ & $43.9^{c}$ & $45.5^{\mathrm{ac}}$ & 1.4 & 0.001 \\
\hline number of Goblet cells & $12.5^{\mathrm{a}}$ & $7.3^{b}$ & $9.0^{\mathrm{ab}}$ & $10.5^{\mathrm{ab}}$ & 1.1 & 0.041 \\
\hline \multicolumn{7}{|l|}{ lleum } \\
\hline villi height, $\mu \mathrm{m}$ & $1000^{a}$ & $1429^{b}$ & $1344^{\mathrm{bc}}$ & $1230^{c}$ & 48.4 & 0.001 \\
\hline crypt depth, $\mu \mathrm{m}$ & $252^{\mathrm{a}}$ & $137^{b}$ & $170^{c}$ & $185^{c}$ & 7.5 & 0.001 \\
\hline villi height:crypt depth ratio & $3.96^{\mathrm{a}}$ & $10.43^{b}$ & $7.44^{c}$ & $6.08^{c}$ & 0.52 & 0.001 \\
\hline villi width, $\mu \mathrm{m}$ & 133 & 191 & 170 & 157 & 13.3 & 0.061 \\
\hline thickness of epithelium, $\mu \mathrm{m}$ & $45.0^{\mathrm{a}}$ & $36.3^{b}$ & $36.9^{b}$ & $39.8^{\mathrm{ab}}$ & 1.7 & 0.021 \\
\hline number of Goblet cells & 12.0 & 8.0 & 9.0 & 10.8 & 1.4 & 0.082 \\
\hline \multicolumn{7}{|l|}{ Jejunum } \\
\hline villi height, $\mu \mathrm{m}$ & 1650 & 1991 & 1948 & 1942 & 90.2 & 0.090 \\
\hline crypt depth, $\mu \mathrm{m}$ & $338^{a}$ & $216^{b}$ & $238^{b}$ & $245^{b}$ & 15.6 & 0.001 \\
\hline villi height:crypt depth ratio & $4.89^{a}$ & $9.20^{\mathrm{b}}$ & $8.32^{\mathrm{b}}$ & $8.02^{b}$ & 0.46 & 0.001 \\
\hline villi width, $\mu \mathrm{m}$ & $121^{a}$ & $198^{b}$ & $175^{\mathrm{ab}}$ & $158^{a}$ & 11.1 & 0.004 \\
\hline thickness of epithelium, $\mu \mathrm{m}$ & 41.1 & 36.9 & 37.0 & 39.3 & 1.1 & 0.065 \\
\hline number of Goblet cells & 9.8 & 6.3 & 6.5 & 6.8 & 1.1 & 0.174 \\
\hline
\end{tabular}

CON - control diet without cracked maize; LDR (low dilution rate diet) - CON + 4 (days 10 to 20 of age, $1^{\text {st }}$ period), 8 (days 21 to 30 of age, $2^{\text {nd }}$ period) and $12 \%$ (days 31 to 42 of age, $3^{\text {rd }}$ period) of cracked maize; MDR (medium dilution rate diet) - CON +6 ( $1^{\text {st }}$ period), 12 ( $2^{\text {nd }}$ period) and $20 \%$ ( $3^{\text {rd }}$ period) of cracked maize; HDR (high dilution rate diet) $-\operatorname{CON}+6$ ( $1^{\text {st }}$ period), 15 ( $2^{\text {nd }}$ period) and $25 \%$ ( $3^{\text {rd }}$ period) of cracked maize. Data presented as least square means; abc - means with different superscripts within the row are significantly different at $P<0.05$; SEM - pooled standard error

from CON group and this effect was connected with crypts deepening in the jejunum (Table 4). Moreover, in broiler chickens from LDR group a reduction of Goblet cells in the duodenum as well as mucosal epithelial thinning in comparison to those from CON group was found (Table 4). Animals from HDR group were characterised by lower villi height, villi height:crypt depth in the duodenum, and villi width in the jejunum in comparison to those from LDR one. Additionally, animals from LDR group had lower crypt depth in the ileum and lower thickness of epithelium in duodenum in comparison to animals from other groups.

\section{Discussion}

In animals fed diet diluted with cracked maize (i.e. from LDR, MDR and HDR groups) the production performance was equall or even better than in those from CON group which had 0.5 to $2 \%$ (in absolute number) grater $\mathrm{CP}$ content. According to Sharma et al. (2012), when cracked maize is added to broiler chicken diets, by sequentially diluting a starter diet up to a level of $40 \%$, then FCR is negatively affected, due to lower CP content of the diet.
In the present study a dilution rate upper limit from 6 to $25 \%$, during productive cycle, was applied and this did not affect negatively the productivity, even had a positive effect on FCR. Moreover, FCR in animals from LDR group was lower in comparison to those from HDR group, because the CP content of the diet was negatively correlated with FCR. This indicated that, in a narrow range of dilution (LDR and MDR treatments), the effect of particle size of maize was more important than the level of the protein level of the diet, but this effect was not valid at higher dilution rates (HDR treatment). It should be noticed that the addition of cracked maize caused changes in the nutrient density of diets (confounding), and this should be taken into account in future studies.

Increasing structural components in the diet, namely through including coarse grain particles, has been shown to improve gut health, feed utilization and production efficiency. This is primarily because structural components physically stimulate the activity in the fore gut (Kheravii et al., 2018). The similar carcass yield and final weight achieved by the addition of whole grains may be related to physical and functional benefits of whole grains in terms of larger, stronger and functional gizzard and the better 
matching of daily requirements through self-selection of the birds (Singh et al., 2014). We have shown that the dilution with cracked maize has beneficial effects for the whole digestive system.

It has been reported that feed particle size influences the development of the gastrointestinal tract and bird performance to a greater extent when the broilers are fed a mash than pellet diets (Zaefarian et al., 2016). According to Naderinejad et al. (2016) broiler chickens fed pellet diets have greater villus height than those fed mash diets. Goblet cell number in the duodenum was higher in birds fed diets containing fine particles in comparison to those fed medium sized or coarser particle sizes. The crypt depth in jejunum was greater in birds fed pellet diets. Coarse grinding of maize is beneficial to nutrient and energy utilization and growth performance in broilers fed pellet diets (Naderinejad et al., 2016) by enhanced gizzard development and functionality, and higher villi height in both the duodenum and jejunum. According to our data these effects are valid also when cracked maize was added to the diet in substitution of pellet diet. Also, present findings suggest that the beneficial effects of the addition of cracked maize are invariable both in crumble and pellet diet (grower and finisher diet, respectively). According to Shabani et al. (2015) broiler chickens fed pellet diet, in comparison to broiler chickens fed mash diet, have greater FI, BWG, carcass weight, breast relative to the carcass weight, better FCR, and lower weight of pancreas, duodenum and cecum relative to the carcass weight. In our study it was revealed that even when pellet diet was replaced by cracked maize, there was a positive response at least when a dilution rate upper level from 6 to $25 \%$, during production cycle, was applied.

The theory that particle size reduction enhances the access of digestive enzymes to substrates because of the increased surface area of feed particles was popular in the past. Anyhow, in broiler chickens, fine particles can negatively affect the development of fore gut (proventriculus and gizzard) playing an important role in intestinal health and nutrient utilization. A well-developed fore gut can be achieved by feeding coarse particles which is associated with improvements in gut motility and health (Zaefarian et al., 2016). In the present study it was revealed that the particle size of broiler chicken diet had notable effects, because the dilution of broiler chicken diets with cracked maize positively affected FCR and digestive system anatomy, regardless the lower $\mathrm{CP}$ level of these diets. The question is whether the above innovative effects could be relying on the distinct digestive system anatomy of poultry, or could be applied in all productive animals.

\section{Conclusions}

The gradual dilution of broiler chicken diets with cracked maize from 6 (grower diets) up to $25 \%$ (in finisher diets) is feasible without any negative effect on productivity, with even a positive effect on feed conversion ratio (FCR). It should be noticed that the addition of cracked maize caused changes in the nutrient density of diets (confounding), and this should be taken into account in future studies. Also, the magnitude of positive responses in animals (no negative effect on body weight gain and FCR) after dilution of the diet with cracked maize allowed the reduction of diet crude protein level to 0.5 (grower diet) and to $2 \%$ (finisher diet). This positive effect of cracked maize addition into the broiler chicken diet was due to higher particle size, which had a beneficial effect on the entire digestive system morphology.

\section{Acknowledgements}

Financial support by Rasht Branch, Islamic Azad University; grant number 17.16.4.8774 is gratefully acknowledged.

\section{References}

Amerah A.M., Ravindran V., Lentle R.G., Thomas D.G., 2008. Influence of feed particle size on the performance, energy utilization, digestive tract development, and digesta parameters of broiler starters fed wheat and corn-based diets. Poult. Sci. 87, 2320-2328, https://doi.org/10.3382/ps.2008-00149

AOAC International, 2006. Official Methods of Analysis of AOAC International. Current through revision 1. $18^{\text {th }}$ Edition. Gaithersburg, MD (USA)

Aviagen, 2009. Ross 308 Broiler: Nutrition Specification. Scotland (UK), pp. 8

Clark P.M., Behnke K.C., Fahrenholz A.C., 2009. Effects of feeding cracked corn and concentrate protein pellets on broiler growth performance. J. Appl. Poult. Res. 18, 259-268, https://doi. org/10.3382/japr.2007-00040

Ebrahimi A., Qotbi A., Seidavi A., Laudadio V., Tufarelli V., 2013. Effect of different levels of dried sweet orange (Citrus sinensis) peel on broiler chickens growth performance. Arch. Anim. Breed 56, 11-17, https://doi.org/10.7482/0003-9438-56-002

Hosseini S.M., Chamani M., Seidavi A.R., Sadeghi A.A., AnsariPirsaraei Z., 2017. Effect of feeding Thymolina ${ }^{\circledR}$ powder on the carcass characteristics and morphology of small intestine in ross 308 broiler chickens. Acta Sci. Anim. Sci. 39, 45-50, https://doi.org/10.4025/actascianimsci.v39i1.32074 
Kheravii S.K., Morgan N.K., Swick R.A., Choct M., Wu S.B., 2018. Roles of dietary fibre and ingredient particle size in broiler nutrition. Worlds Poult. Sci. J. 74, 301-316, https://doi. org/10.1017/S0043933918000259

Naderinejad S., Zaefarian F., Abdollahi M.R., Hassanabadi A., Kermanshahi H., Ravindran V., 2016. Influence of feed form and particle size on performance, nutrient utilisation, and gastrointestinal tract development and morphometry in broiler starters fed maize-based diets. Anim. Feed Sci. Technol. 215, 92-104, https://doi.org/10.1016/j.anifeedsci.2016.02.012

Pacheco W.J., Stark C.R., Ferker P.R., Brake J., 2013. Evaluation of soybean meal source and particle size on broiler performance, nutrient digestibility, and gizzard development. Poult.. Sci. 92, 2914-2922, https://doi.org/10.3382/ps.2013-03186

Plavnik I., Macovsky B., Sklan D., 2002. Effect of feeding whole wheat on performance of broiler chickens. Anim. Feed Sci. Technol. 96, 229-236, https://doi.org/10.1016/S0377-8401(01)00321-2

SAS Institute, 2003. SAS/STAT User's Guide, Version 9. SAS Inst. Inc., Cary, NC (USA)

Shabani S., Seidavi A.R., Asadpour L., Corazzin M., 2015. Effects of physical form of diet and intensity and duration of feed restriction on the growth performance, blood variables, microbial flo$\mathrm{ra}$, immunity, and carcass and organ characteristics of broiler chickens. Livest. Sci. 180, 150-157, https://doi.org/10.1016/j. livsci.2015.07.006
Sharma N.K., Sapkota M., Sah R., Sharma M.P., Creswell D., Sharma N., 2012. Performance and carcass characteristics of broilers under diets supplemented with whole grains. Nepal J. Sci. Technol. 13, 21-28, https://doi.org/10.3126/ njst.v13i2.7709

Singh Y., Ravindran V., Wester T.J., Molan A.L., Ravindran G., 2014. Influence of feeding coarse corn on performance, nutrient utilization, digestive tract measurements, carcass characteristics, and cecal microflora counts of broilers. Poult. Sci. 93, 607-616, https://doi.org/10.3382/ps.2013-03542

Svihus B., Sacranie A., Denstadli V., Choct M., 2010. Nutrient utilization and functionality of the anterior digestive tract caused by intermittent feeding and inclusion of whole wheat in diets for broiler chickens. Poult. Sci. 89, 2617-2625, https://doi. org/10.3382/ps.2010-00743

Xu Y., Stark C.R., Ferket P.R., Williams C.M., Brake J., 2015. Effects of feed form and dietary coarse ground corn on broiler live performance, body weight uniformity, relative gizzard weight, excrete nitrogen, and particle size preference behaviors. Poult. Sci. 94, 1549-1556, https://doi.org/10.3382/ps/pev074

Zaefarian F., Abdollahi M.R., Ravindran V., 2016. Particle size and feed form in broiler diets: impact on gastrointestinal tract development and gut health. Worlds Poult. Sci. J. 72, 277-290, https://doi.org/10.1017/S0043933916000222 